\title{
A Samaritan Manuscript in McGill University
}

\author{
by Reinhard Pummer
}

The Samaritans are a religio-ethnic group that developed out of Judaism in the last centuries before the turn of the era. Their sacred centre is Mount Gerizim near Nablus, ancient Shechem, and not Jerusalem. When their sanctuary on the mountain was destroyed by the Hasmonean John Hyrcanus in the second century B.C.E., Judaism and Samaritanism separated and pursued their own ways. Today the Samaritans number 550 individuals.

The only part of the Bible that is recognized by the Samaritans is the Pentateuch or the Five Books of Moses. Because it is central to their faith it is copied in every generation many times. Unfortunately, numerous manuscripts have perished; others were sold by the Samaritans to European scholars and collectors. The proceeds from the sales were used to improve their often bleak economic situation.

The McGill Samaritan Pentateuch was bought by the University in 1921. It was written in 1911 and remained in the possession of the Samaritans until 1913 when it was sold for the first time to outsiders.

The manuscript is a very well written and preserved copy of the whole Pentateuch. It is interesting not only with regard to the Samaritan version of the text, but also in palaeographical and codicological respects. Moreover, the information contained in the colophon and an Arabic note at the end of the volume adds to our knowledge of Samaritan scribes and the history of Samaritan manuscripts.

Les Samaritains forment une secte etbno-religieuse issue du judaïsme dans les derniers siècles avant le tournant de notre ère. Leur lieu saint est le mont Garizim près de Nablus, l'ancien Sichem, et non pas Jérusalem. Lorsque leur temple du mont Garizim fut détruit par Jean Hyrcan, grand prêtre asmonéen au $I I^{\circ}$ siècle av. J.-C., Judéens et Samaritains se scindèrent. Les Samaritains ne sont plus aujourd'bui que cinq cent cinquante environ.

Le seul livre de la bible reconnu par les Samaritains est le Pentateuque ou les cinq livres de Moüse. Étant donné qu'il est au cœur de leur foi, il est recopié maintes fois par chaque génération. Malbeureusement, de nombreux manuscrits ont disparus; d'autres ont été vendus par les Samaritains à des érudits et des collectionneurs européens. Les produits de ces ventes servaient à améliorer leur situation économique souvent précaire.

Le Pentateuque samaritain de McGill a été acbeté par l'Université en 1921. Il a été écrit en 1911 et est resté en la possession des Samaritains jusqu'en 1913 lorsqu'il a été vendu pour la première fois à des gens de l'extérieur.

Le manuscrit est une copie admirablement bien écrite et préservée de l'ancien Pentateuque. Il est intéressant non seulement sous l'angle de la version samaritaine du texte, mais également d'un point de vue paléographique et codicologique. Par ailleurs, les renseignements que contient le colophon et une note en arabe à la fin du volume renouvellent nos connaissances sur les scribes samaritains et sur l'bistoire des manuscrits samaritains. 


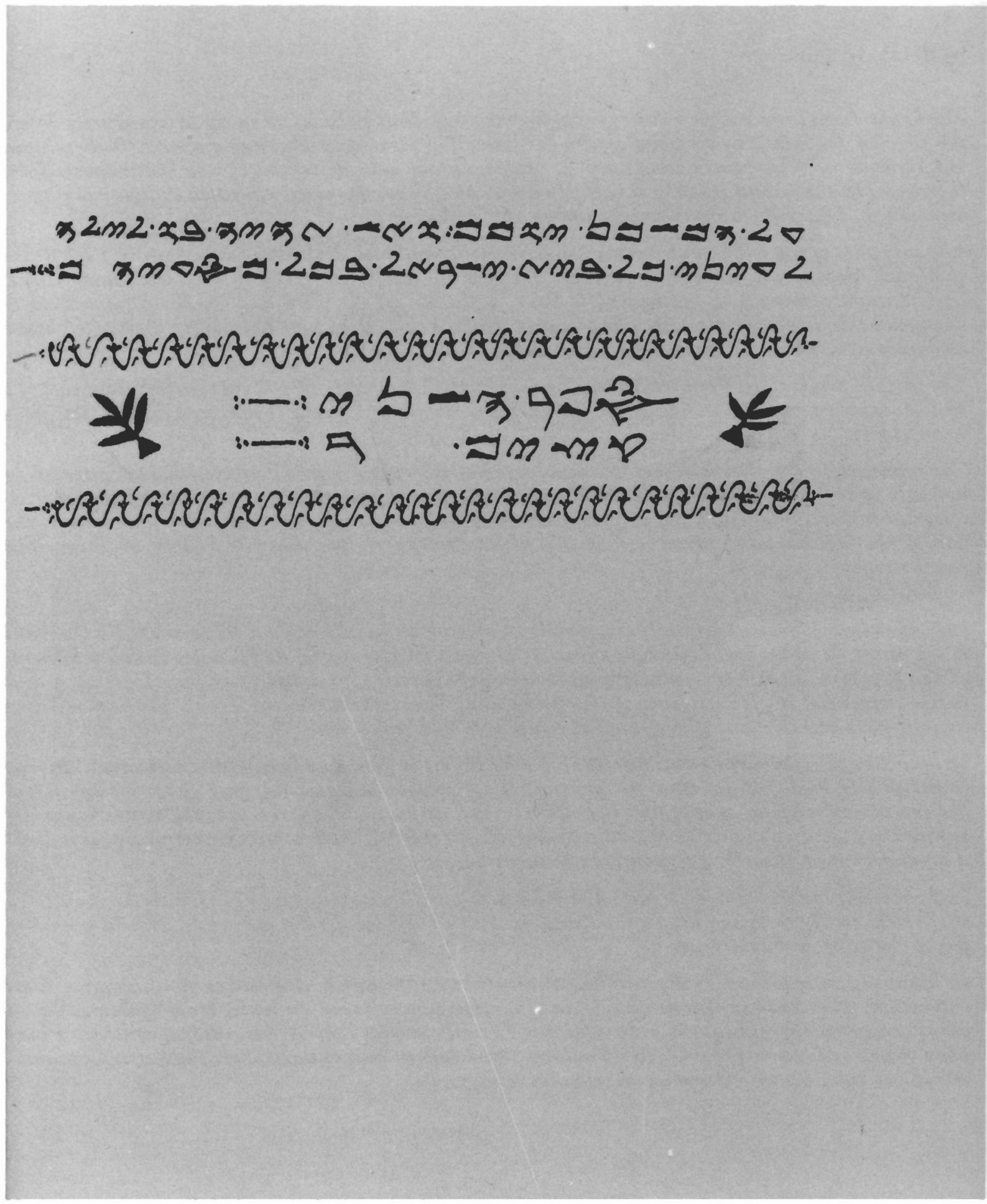

Figure 1. The end of the book of Exodus (40:38). Between the decorative lines: "Second book. 200 sections (qissem)." 


\section{A Samaritan Manuscript}

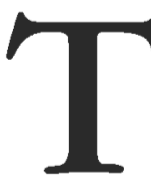

he Samaritans are well known from several accounts in the New Testament, especially the parable of the Good Samaritan in Luke $10: 25-37$. What is not as widely known is the fact that there are still Samaritans alive in our time. They are a very small religio-ethnic community who live in two cities in Israel, Nablus and Holon. Nablus, ancient Shechem, is located by their holy mountain, Mount Gerizim, which has always been the focus of their faith. Holon is located south of Tel Aviv where Samaritans have settled in modern times. They number approximately 550 individuals in all; half of them live in Nablus, half in Holon.

The matrix from which Samaritanism developed is Judaism. The gradual development of a group of Yahweh worshipers in Samaria who did not accept Jerusalem as the centre, ended in a final break with Judaism in the late 2 nd cent. B.C.E. when the Hasmonean priest-king John Hyrcanus (134-104 B.C.E.) destroyed their sanctuary on Mt. Gerizim as the Jewish historian Flavius Josephus (1st cent. C.E.) reports. ' From then on Samaritans and Jews went their separate ways.

In Graeco-Roman times the Samaritans may have numbered as many as two hundred thousand, the majority of them living in Palestine and others in the diaspora in Egypt, Greece, Rome and other cities and countries. However, persecutions by Byzantine and Muslim rulers reduced their numbers drastically, until there were only 130 to 150 individuals left in the 19th cent. Many observers predicted their imminent disappearance. But the opposite has happened. A number of Samaritan men married Jewish women who agreed to live as Samaritans, and the size of the community gradually rose and is still on the increase.

The Bible of the Samaritans consists only of the Pentateuch or the Five Books of Moses or the Torah. While the Samaritans and the Jewish Pentateuch are essentially the same they do differ from each other. However, only a small number of passages reflect specific Samaritan beliefs; the majority of the differ- ences concern textual matters that have no bearing on the contents.

In their synagogue in Nablus the Samaritans preserve a Torah scroll that, according to their beliefs, was written by Abisha, the great grandson of Aaron, in the thirteenth year of the entry of the Israelites into the Holy Land. However, modern research has shown that the oldest biblical manuscripts of the Samaritans do not antedate the 10 th $/ 11$ th centuries of the Christian era.

Their great veneration for the Bible has prompted the Samaritans to copy its text in each generation numerous times, either in the form of a scroll or in that of a codex. Unfortunately, many of the old manuscripts are no longer extant. Those that are available for study are of interest not only under the aspect of the biblical text, but also because they contain data that help to reconstruct Samaritan history. For considerable spans of time our information about the Samaritans is very incomplete. It is therefore necessary to draw on all available sources that can shed light on the social and religious development of the community. Pentateuch manuscripts contain colophons, deeds of sale and frequently additional notes that allow us to learn a great amount about Samaritan scribal traditions, the history and fortunes or, more often misfortunes, of individuals and families, and sometimes even about the economic situation of the group.

For many centuries the Samaritans had to endure hardships at the hands of their overlords. As a consequence they often lived under extremely destitute conditions. One way in which they tried to alleviate their poverty was to sell manuscripts, ancient as well as modern, to Europeans and eventually to North Americans. A small number of such manuscripts have found their way into Canadian libraries.

The Royal Ontario Museum in Toronto holds three from the 18th cent. and the Thomas Fisher Rare Book Library of the University of Toronto possesses one from 1911. The manuscripts in the Royal Ontario Museum contain the text of the pentateuchal books of Leviticus, Numbers, and 


\section{A Samaritan Manuscript}

Deuteronomy respectively; the manuscript in the University of Toronto is a scroll of the whole Samaritan Pentateuch. They were acquired in Nablus in 1910 and 1912. ${ }^{2}$ An additional manuscript, so far not listed in any of the surveys of manuscripts in European and North American libraries, ${ }^{3}$ is the property of McGill University Library. ${ }^{4}$ It is a complete Pentateuch codex in excellent condition. A handwritten note in pencil on the rear pastedown records that the manuscript was "bought from the Samaritan High Priest in 1913 in London." Neither the name of the seller nor that of the buyer is given.

In 1897 , Isaac b. Salamah ${ }^{5}$ went to France and England to secure help for the impoverished community. He was only moderately successful in his fund raising, but he found a keen interest in Samaritan manuscripts among European scholars. Thus, in 1903, three priests were sent to London to offer manuscripts for sale; ${ }^{6}$ besides Isaac b. Amram b. Salamah, Ozzi b. Jacob and Abisha b. Pinhas were chosen.' A fourth member of the delegation was Jacob esh-Shelabi who had been to London in 1854/55 and has left a description of the plight of the Samaritans in the 19th cent. ${ }^{8}$ Among the buyers in 1903 were M. Gaster, D. S. Sassoon, the British Museum, and others.'

According to the handwritten note in the McGill manuscript, the year in which it was bought was 1913. Although no delegation went to Europe in that year, some elders of the community do remember that Isaac b. Amram undertook a journey on his own to London and Paris in 1913. ${ }^{10}$ The same note further states that the manuscript was bought "from the Samaritan High Priest." Neither Isaac b. Amram nor the other two priests who were in London were high priests at the time of their visits. However, Isaac introduced himself as the most senior priest and caused some who met him to call him "High Priest." This led to serious tensions between him and Jacob b. Aaron, who in fact was the high priest at the time. ${ }^{11}$

In a letter to the eminent English orientalist and scholar of Samaritanism, A. E. Cowley (1861-1931), written after Isaac's return from his first journey to Europe, Jacob b. Aaron bit- terly complains about his cousin. According to Jacob, Isaac wrote in newspapers that he was the Samaritan high priest, that he had authored many works, was unique in his generation in his wisdom and knowledge, and that no one like him could be found among the Samaritans. But, says Jacob, everyone in the community knows that these claims are all lies and that, in fact, Isaac is notorious for his mendacity. 12 On November 28, 1902, Jacob b. Aaron wrote another letter about Isaac, this time in French; it was directed to $M$. Benveniste, director of the Boys School in Jerusalem. Again, Jacob protested against Isaac's claim to be the Samaritan high priest. ${ }^{13}$ Only in 1916 did Isaac b. Amram finally take over the office. ${ }^{14}$

The second time that the McGill manuscript was offered for sale was by Maggs Bros. of London in their catalogue no. 404, Illuminated Manuscripts and Miniatures, European and Oriental, in 1921. McGill University bought it on September 15, 1921, for $£ 21$, the price listed in the catalogue. ${ }^{15}$ The latter described it as a "Samaritan manuscript of excessive rarity, written on Syrian white paper, in black, in the original ancient Samaritan characters. Small folio, original Samaritan binding of leather with flap. XIXth Century." ${ }^{16}$ The contents of the handwritten note are also repeated in the catalogue's description.

The size of the pages of the manuscript is $24.5 \times 37.0 \mathrm{~cm}$; the widths of the margins are $7.5 \mathrm{~cm}$ at the top, $5.0 \mathrm{~cm}$ at the bottom, 6.0 -6.5 on the outer side, and $2.3 \mathrm{~cm}$ by the spine. It consists of 23 quires of 10 leaves each, ${ }^{17}$ except for the last quire which has only 4 plus 2 leaves. The whole manuscript consists therefore of 226 folios. The green threads with which it is sewn, are held in place by two pieces of wood on the top and bottom of the spine. The binding is an Islamic flap binding. ${ }^{18}$ There is no foliation, nor are there any catchwords.

As is usual in Samaritan manuscripts, guiding lines were impressed on the paper; horizontal lines on which to "hang" the letters, vertical lines to delineate the width of the text, to mark off the first letter of each line, and, in certain places, to mark columns. There are 


\section{A Samaritan Manuscript}

- $\gg<\mathbb{4}$

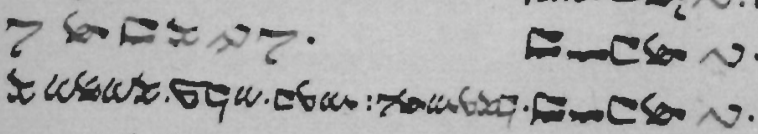

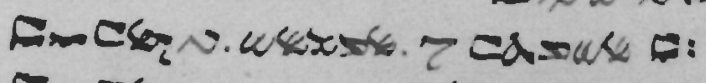

$>\cos 6 \sec$.

a-cen.

$\operatorname{sen} 0 x+7 k:$

$7 C G \mathrm{ces}$.

$\rightarrow-\infty \omega \infty$.

$\cos \operatorname{sen} 6 x \in 0:$

$7=28$

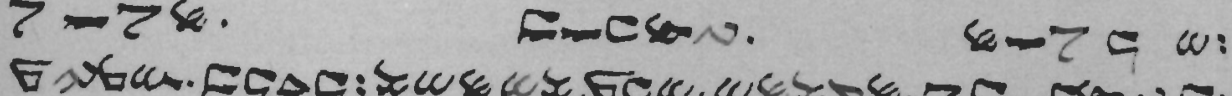

secoseco:

sectur w: जqw.

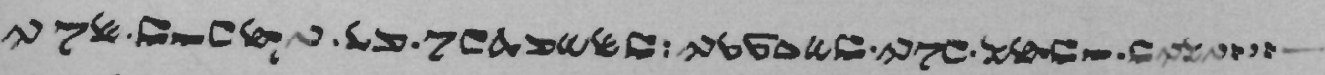

7 N⿴囗十 4 .

$0-\cos$.

catos? w:

$7 N G x>m$.

E-ceson.

$\log _{0} t 0 \mathrm{w}$

$7 \Delta b k$.

Ancrow.

sol w:

7 Naqu.

ancson.

4as? w:

7 mqu.

onceson.

$x-x=\infty:$

$7 \sin \alpha$.

Encson.

seses w:

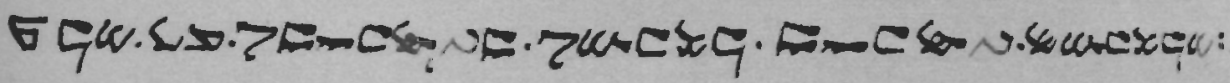

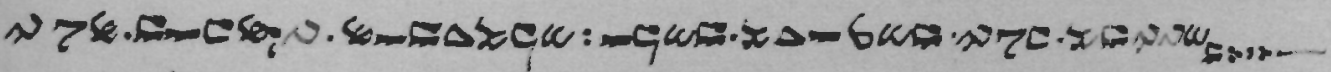

$?-\infty \leq ⿰ ㇇ ⿰ 亅 ⿱ 丿 丶 丶]$.

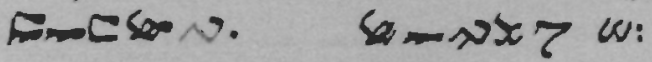

7 S 6 Go.

ancson. $\operatorname{sen} 6 \operatorname{sen} \omega:$

ᄀ WA WC.

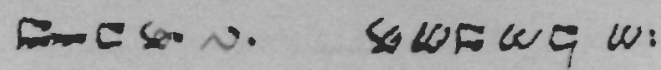

7 uЕw⿻.

-

ᄀ

-

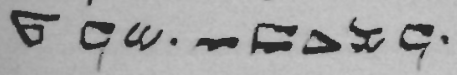

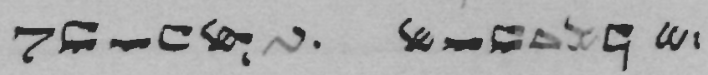

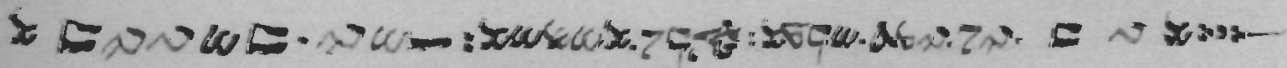

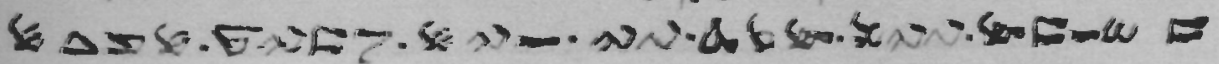

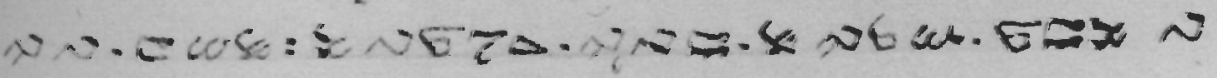

Figure 2. Numbers 26:10-22. Note the alignment of letters and words. 


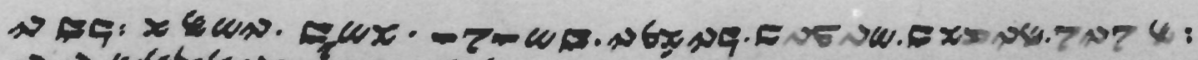

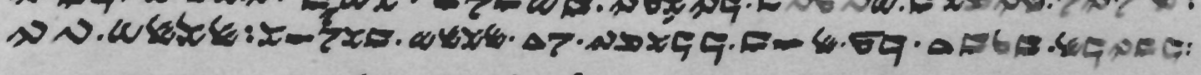

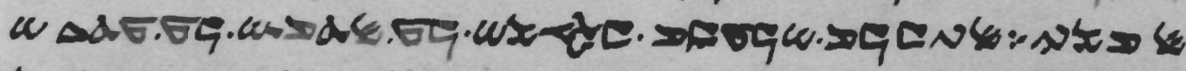

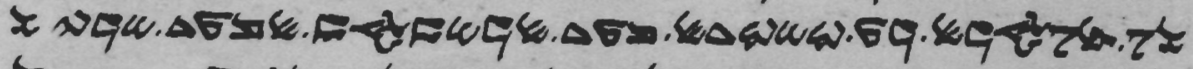

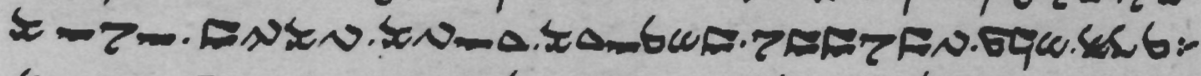

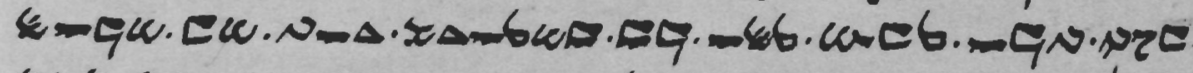

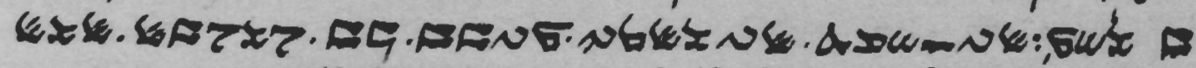

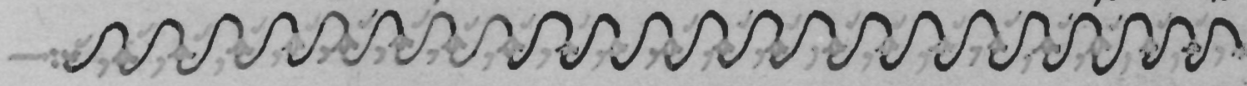

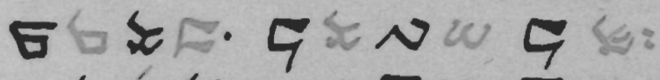

$$
\begin{aligned}
& \text { N5E. NEW E E: }
\end{aligned}
$$

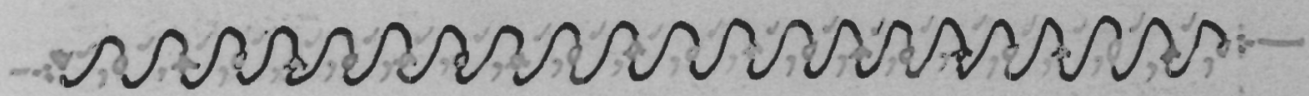

$$
\begin{aligned}
& \text { a w w } \\
& \frac{d}{\sigma} \sigma \in \cdot \cos =\omega-w
\end{aligned}
$$

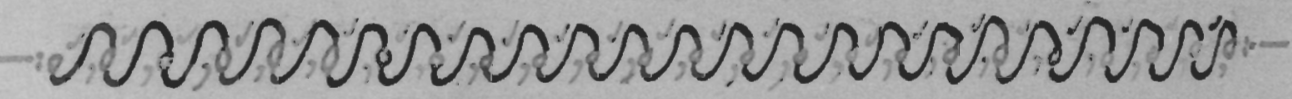

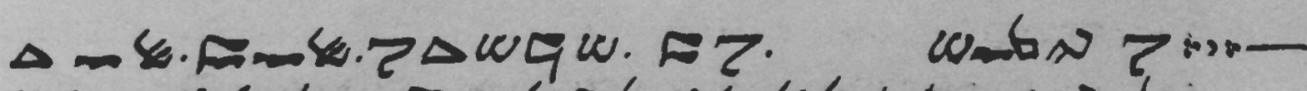

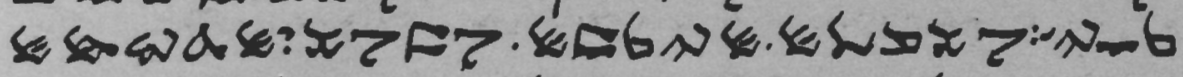
$\triangle \sigma$ -

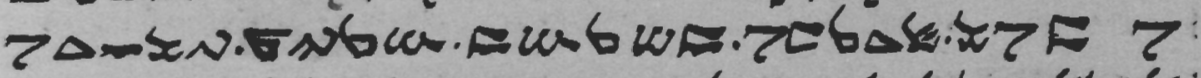

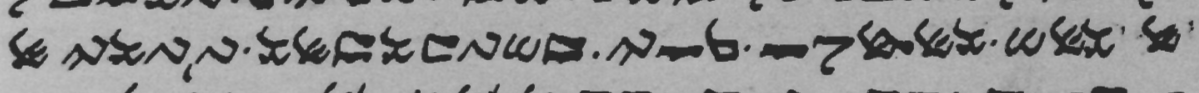

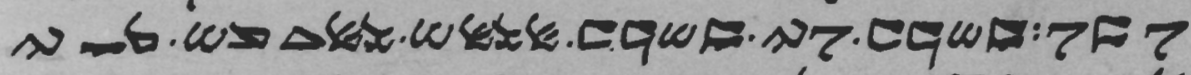

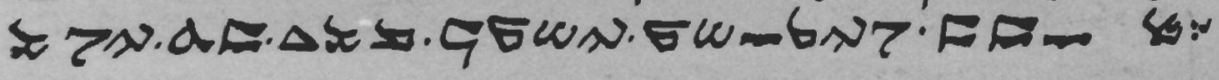

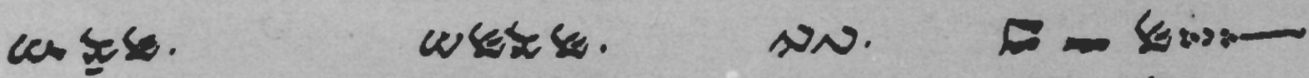
$\$$ w

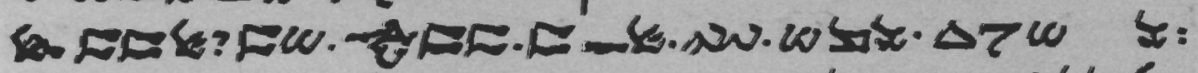

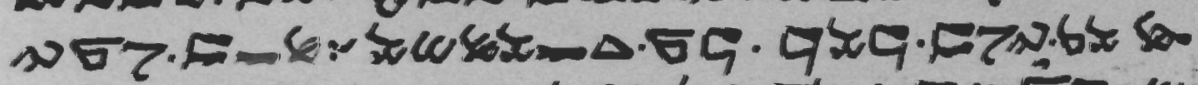

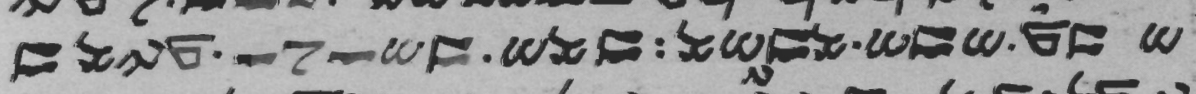

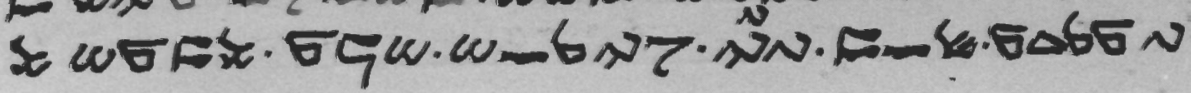

Figure 3. Deuteronomy 34:8-12. Between the first two decorative lines: "Fifth book. 160 sections (qissem)." Below the second and above the third decorative line: "A complete Torah; blessed be its giver." Bottom of the page: Colophon. 


\section{A Samaritan Manuscript}

30 lines per page, without exception throughout the whole manuscript. The method used for lining was obviously that of the mastara, or ruling-board in Arabic. Ruling-boards were produced by threading cords "into grooves, forming ridges corresponding to the horizontal and the vertical bounding lines." ${ }^{19}$ By placing the leaves of the manuscript on the board and rubbing along the cords, impressions were left that served as lines. The technique is still used in modern times by the Samaritans of Nablus, with the ruling-boards made of cardboard ${ }^{20}$ As to the size of the letters, there are 12 to 16 letters per $10 \mathrm{~cm}$; they are larger in the beginning and decrease from Gen. 20 on. The writing is majuscule throughout the whole text, including the remarks at the end of the books.

The paper is fine white paper except for a number of folios for which rougher paper was used. ${ }^{21}$

Corrections such as erasures and insertions of letters and words occur in several places. Very few diacritical marks were used.

The manuscript contains no tashqil or cryptogram. ${ }^{22}$ Its excellent state shows that is was never used for recitation or study. On the other hand, from an Arabic note at the end it becomes clear that it was not written for the purpose of selling it to non-Samaritans. ${ }^{23}$

Folio $\mathrm{lr}$ is glued to the inside front cover, i.e., we have before us a "first folio pastedown." The Samaritans developed a technique "whereby the first sheet and the last sheet of the manuscript were used as pastedowns" and served thus as doublures and end papers. ${ }^{24}$

Fols. 1v - 61 r contain the text of Genesis, $62 v-105 v$ Exodus, 106v - 138v Leviticus, $139 \mathrm{v}-189 \mathrm{r}$ Numbers, and 189v - 225r Deuteronomy. Fol. 225v contains a note in Arabic. ${ }^{25}$ Fol. 226 is blank.

The end of the sections of the Samaritan Pentateuch, called qissem, is indicated by the sign $-. . \cdot:<\because ;$ the sections are separated by a blank line and their number is listed after each book except for the book of Numbers: Genesis 250, Exodus 200, Leviticus 130, and Deuteronomy 160 (Figures 1, 2 and 3). They correspond to the usual numbers. The notes on the number of the qissem are preceded by the number of the respective book, e.g. ספר הראישון , "the first book," after Genesis. Decorative lines are placed before and after these notes; red ink is used for the lines and the annotations after Exodus (Figure 1), Leviticus and Deuteronomy (Figure 3). There are two branch-like drawings at the end of Exodus. ${ }^{26}$ After the number of qissem for Deuteronomy follows ברוך נותינה -

"a complete Torah; blessed be its giver" (Figure 3).

In numerous places words or letters are arranged in such a way that the same words or letters appear one under the other (Figure 2). This arrangement came to function as a decorative device and is used not only in the Pentateuch but in many other Samaritan manuscripts, including liturgical ones. But it is possible that once, i.e. prior to the 13th cent. C.E., it had a Massoretic function which may go back to antiquity and was later forgotten. ${ }^{27}$ Exod. 15:1-21 (Song of the Sea), Num. $23: 7^{28}-10 ; 18-25 ; 24: 3-10$ (sic); $15-25$ (sic) (oracles of Balaam), and Deut. 32:1 - 43 (the ) are written in two columns.

On fol. 225r (Figure 3), after the record of qixem and the above cited statement about the complete Torah, the scribe identified himself and gave the date on which he finished his work. The text, transliterated into square Hebrew characters, reads as follows:

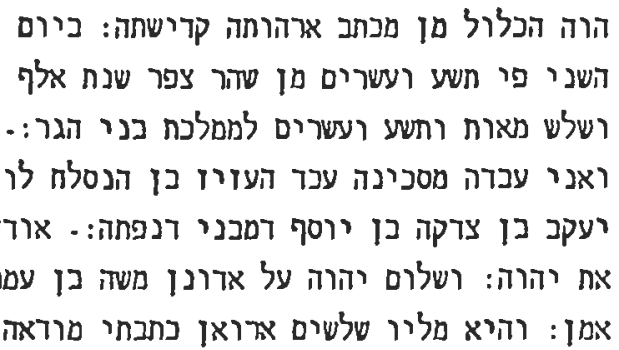

This is the end of the writing of the Holy Torah, on Monday,

the twenty ninth of the month Safar of the year thousand

three hundred and twenty nine of the rule of the sons of Hagar. 


\section{A Samaritan Manuscript}

I am the poor servant Abd Ha'Aziz b. Jacob (may he be forgiven)

b. Sadaqah b. Joseph of the Danfi family. I thank Yahweh; the peace of Yahweh be on our lord Moses b. Amram, the faithful.

Amen. This is the thirtieth Torah which I have written. Thanks be to God.

The date of completion, 29 Safar 1329 A.H., corresponds to March 1, 1911, which was, though, a Wednesday and not a Monday; this is not unusual since, for various reasons, ${ }^{29}$ Islamic dates cannot always be precisely equated with Gregorian dates.

The scribe, Abd Ha'Aziz b. Jacob b. Sadaqah b. Joseph of the Danfi family, is known from several other manuscripts that he copied. As he states at the end of the colophon, the McGill manuscript was his 30th copy of the Pentateuch. ${ }^{30}$ In 1331 A.H., i.e. between December 11, 1912 and November 29, 1913 C.E. he wrote his 36th Torah which is now in the John Rylands University Library of Manchester, England (Ryl Sam 35). Since he died before he could complete it, Abisha b. Pinhas, copyist, hymn writer and high priest from 1943 to 1960 (b. 1880), finished it at the end of $\operatorname{Rabi}^{\mathrm{i}}$ I 1336 A.H., ${ }^{31}$ i.e. before January 14, 1918.

Instead of signing his name as $\mathrm{Abd} \mathrm{Ha}$ 'Aziz b. Jacob, the same copyist sometimes simply wrote "Aziz b. Jacob." So, e.g., in the Torah manuscripts Ryl Sam 49, completed in 1315 A.H., i.e. $1897 / 98$ C.E., and Ryl Sam 92, completed at the end of 1318 A.H., i.e. in February/March 1901 C.E. Furthermore, Abd Ha'Aziz b. Jacob is the copyist of Ryl Sam 107, finished on Thursday, 20 Rajab 1322 A.H., i.e. September 30, 1904 C.E., and that of BL Or 10814, finished on 23 Muharram 1328 A.H., i.e. February 4, 1910 C.E.; ${ }^{32}$ both are Pentateuch manuscripts. He also copied Leeds University Sam. 1,3.33 Other manuscripts copied by him are now held by the Bibliothèque Nationale in Paris; they are liturgical texts. ${ }^{34}$ In one of them, BN Sam. $50,{ }^{35}$ the designs are reminiscent of the two figures after the book of Exodus in the McGill Pentateuch. ${ }^{36}$

Other forms of Abd Ha'Aziz b. Jacob's name are Aziz b. Jacob b. Shelabi b. Joseph b. Murjan (Ab Sakhwah) ${ }^{37}$ and Aziz b. Jacob b. Shelabi. ${ }^{38}$

In the census list of Samaritan males from the year 1908, Aziz b. Jacob is listed as no. 14, born in 1294 A.H., i.e. between January 16, 1877 and January 4, 1878; in 1908 he was thus 31 years old. On the basis of MS sam N22 from the year 1335 A.H., i.e. $1916 / 17$ C.E., ${ }^{39}$ it can be calculated that he must have died before or at the age of $42 .^{40}$ Despite his short life he was an accomplished copyist who left behind many manuscripts.

Fol. $225 \mathrm{v}$ contains a note in Arabic which was written by Hilmi b. Jacob Halabi. It states that Hilmi b. Jacob gave this Torah to Ghazzal, son of the late Khadr, the levitical priest, although it had not been written by himself but by his brother Aziz b. Jacob. Hilmi b. Jacob Halabi is no. 15 in the male census list of 1908 ; his birthdate was 1296 A.H. A number of Arabic manuscripts copied by him are in the library of the late high priest Amram b. Isaac in Nablus, ${ }^{41}$ one in the Freie Universität Berlin, ${ }^{42}$ and one in the Library of Congress. ${ }^{43}$ The Samaritan manuscript 234 in the John Rylands University Library of Manchester contains a long colophon in Arabic where Hilmi b. Jacob, Shelabi, ${ }^{44}$ of the Danfi family, notes that he finished the work, a chronicle, on 4 Ramadān 1326 A.H., i.e. September 30, 1908 C.E. ${ }^{45}$

In the Paris MS Sam. 53 which contains prayers for the six Sabbaths preceding Pentecost, ${ }^{46}$ Hilmi Halabi Samari noted on fol. 18r that he finished his work on 29 DhūlQa'da (I) (1)314 A.H., i.e. May 1, 1897 C.E., for his brother Aziz Halabi, the scribe of the McGill Pentateuch; on fol. 52r Aziz b. Jacob b. Halabi ad-Dananfi records the completion of the work on 17 Muharram 1317 A.H., i.e. May 28, 1899. ${ }^{47}$ The manuscript is thus a joint work of the two brothers.

Finally, the person who received the manuscript, Ghazal, son of the late Khadr, Levitical priest, was also a well known Samaritan copyist; the Samaritan equivalent of his name is Tabiah b. Pinhas. ${ }^{48} \mathrm{He}$ was born in 1885 , as can be calculated from the male census list of 1908, where he is no. 9; his occupation is given as "copyist." 49 


\section{A Samaritan Manuscript}

The note which records the transfer is undated and does not disclose what Hilmi b. Jacob Halabi received for the manuscript. From Ghazal b. Khadr the Pentateuch must have passed to a European buyer in 1913, two years after Aziz b. Jacob b. Sadaqah had completed it. It then came into the possession of Maggs Bros. in London and, in 1921, it was acquired by McGill University.

The McGill Samaritan Pentateuch manuscript is not only exquisitely executed, but also adds to our store of information about Samaritan personalities of the late 19th and early 20th century. Moreover, it is the only complete manuscript of a codex of the Samaritan Bible in a Canadian library as far as is known at the present time. As opposed to the scroll in Toronto, the manuscript was initially not copied for the purpose of selling it to Western buyers but for members of the Samaritan community. And it remained in the possession of Samaritans until poverty forced them to part with it.

\section{Notes}

1. Jewish Antiquities 13:255-256 // Jewish War $1: 63$. Cf. also the most recent excavations on the main peak of Mt. Gerizim, I. Magen, "Mount Gerizim - A Temple City," Qadmoniot 91-92 (1990), 70-96 (Hebrew).

2. Cf. R. Pummer, "Samaritan Manuscripts in Toronto," Revue de l'Université d'Ottawa 46 (1976), 345-363.

3. It is not included in J.D. Pearson, Oriental Manuscripts in Europe and North America: A Survey (Bibliotheca Asiatica, 7; Zug, Switzerland: Inter Documentation Company AG, 1971), nor in J.-P. Rothschild's most useful guide to collections and catalogues entitled "Samaritan Manuscripts," in A.D. Crown, ed. The Samaritans (Tübingen: J.C.B. Mohr [Paul Siebeck], 1989), $771-794$.

4. I am grateful to Mr. Brad Hill, formerly of Ottawa, now curator of Hebrew books and manuscripts in the British Library in London, for bringing the manuscript to my attention. 5. The spelling of Samaritan names follows that of A.D. Crown in his "An Index of Scribes, Witnesses, Owners and Others Mentioned in Samaritan Manuscripts, with a Key to the Principal Families Therein" (= "Studies in Samaritan Scribal Practices and Manuscript History: IV") in Bulletin of the Jobn Rylands University Library of Manchester [BJRUL] 68 (1986), 317-370.

6. A list of manuscripts which the Samaritan delegation was to bring with them is contained in a letter of Isaac b. Amram to A. E. Cowley; the letter is now in the Bodleian Library in Oxford (MS Sam. E 19,2); the text was re printed in A. B. - The Samaritan News 421-422 (15.10.1986), 40

7. See A.-B. - The Samaritan News 148 (14.11.1975), 2.

8. E. T. Rogers, ed. Notices of the Modern Samaritans, Illustrated by Incidents in the Life of Jacob esh-Shelaby. London: Sampson Low and Son, 1855. On Jacob esh-Shelaby see also J. Mills, Three Months' Residence at Nablus, and an Account of the Modern Samaritans (London: John Murray, 1864), 182-183; J. A. 


\section{A Samaritan Manuscript}

Montgomery, The Samaritans (Philadelphia, 1907; repr.: New York: Krav, 1968), 10-11, 140-141 and the photograph between pp. 140 and 141 ; and Y. Shavit, Y. Goldstein, H. Be'er, eds. Personalities in Eretz-Israel 1799-1948: A Biographical Dictionary (Tel Aviv: Am Oved, 1983), 256-257 (Hebrew) [quoted in the following as Personalities].

9. I want to thank Mr. Benjamim Tsedaka for providing information on the Samaritan delegation in 1903; Mr. Tsedaka, together with his brother Yefet, is director of the "Institute for Samaritan Studies" in Holon and editor of the bi-weekly periodical $A, B .-T h e$ Samaritan News.

10. Oral information from B. Tsedaka, November 1, 1991.

\section{Cf. Personalities, 256.}

12. The letter is now in the Bodleian Library in Oxford (MS Sam. E 19,1); its text is re-printed in $A$. B. - The Samaritan News 421-422 (15.10.1986), 39-40.

13. The letter is now in the John Rylands University Library of Manchester (Ryl Sam 346, formerly Gaster 2105 A,2 [the original] and 3 [a copy]); cf. E. Robertson, Catalogue of the Samaritan Manuscripts in the Jobn Rylands Library of Manchester II (Manchester: John Rylands Library, 1962), cols. 261-262.

14. Always the oldest member of the priestly family becomes high priest.

15. I am indebted to Dr. R. Virr, curator of manuscripts, McGill University, for this information.

16. The date was obviously not based on a reading of the colophon as will be seen below.

17. Quires of 5 sheets ( 10 leaves) are usual in the Orient, see M. Bet-Arié, Hebrew Codicology (Jerusalem: the Israel Academy of Sciences and Humanities, 1981), 44.

18. For a thorough description of this kind of binding, including an illustration, see A. D. Crown, "Studies in Samaritan Scribal Practices and Manuscript History: V. Samaritan Bindings: A Chronological Survey with Reference to Nag Hammadi Techniques" BJRUL 69 (1987), especially pp. 449 (Plate 3),
460-463, and 476 .

19. Beit-Arié, Hebrew Codicology, 80.

20. Cf. Beit-Arié, Hebrew Codicology 80 and Pl. 18, the phohtograph of a ruling-board made by Joseph b. Hisda. Cf. Also A. D. Crown, "Studies in Samaritan Scribal Practices and Manuscript History: II. The Rate of Writing Samaritan Manuscripts and Scribal Output" BJRUL 66 (1983-84), 109-110.

21. On paper in Samaritan manuscripts see A. D. Crown, "The Morphology of Paper in Samaritan Manuscripts: A Diachronic Profile," in BJRUL 71 (1980) 71-93; on p. 89 he points out that Samaritan scribes often mixed paper from different batches.

22. A tashqil gives the name of the scribe and the date of the manuscript within the text, i.e., the scribe leaves a small space between the letters that he uses to create the information, and the running text; his name and the date of the manuscript can be found by reading the isolated letters from top to bottom (see Pummer, "Samaritan Manuscripts" 349).

23. For the note see page 168.

24. See Crown, "Studies" II, p. 481.

25. See page 168.

26. Cf. Figure I. See page 168 for similar drawings in the manuscript Paris, BN Sam. 50.

27. This is A. D. Crown's conclusion in his article "Studies in Samaritan Scribal Practices and Manuscript History: III. Columnar Writing and the Samaritan Massorah" BJRUL 67 (1984-85); see particularly pp. 355 and 379-380.

28. מארם instead of מחרם

29. See A. Grohman, Arabische Chronologie (Handbuch der Orientalistik. Erste Abteilung: Der Nahe und der Mittlere Osten. Ergänzungsband II. Erster Halbband. Leiden/ Köln: E.J. Brill, 1966), 39. Cf. also S. Powels, Der Kalender der Samaritaner anband des Kitāb hisāb as-sinin und anderer Handschriften (Studia Samaritana, 3; Berlin - New York: Walter de Gruyter, 1977), 38-42, and 
M. Baillet, "Samaritans" (Supplément au Dictionnaire de la Bible, Fasc. 63-64A [1990]), 894.

30. In 1328 A.H., i.e. 1910 C.E., he copied, this time in cursive Samaritan script, the Samaritan Targum, i.e. the Aramaic translation of the Pentateuch, (MS Sassoon 390); see D. S. Sassoon, Obel Dawid. Descriptive Catalogue of the Hebrew and Samaritan Manuscripts in the Sassoon Library, London (London: Oxford University Press, 1932), 584-585.

31. See Robertson, Catalogue II, col. 10.

32. Cf. Tafel VI,1 in Z. Shunnar, Katalog Samaritanischer Handschriften Vol. 1 (Berlin: Richard Seitz, 1974).

33. See A. D. Crown, "Studies" IV, no. 237; the dates of the Leeds manuscripts are unknown to me.

34. In some cases only a section was copied by him, not the complete manuscript.

35. It is dated 23 Jumāata $I$ [1] 312 , i.e. November 22, 1894.

36. For illustrations see Plates XXX and XXXI in J.-P. Rothschild, Catalogue des manuscrits samaritains (Paris: Bibliothèque Nationale, 1985). The other manuscripts are: Sam. 61 (15 $\mathrm{Rabi}^{-c}$ '[1?] [1] 316 A.H., i.e. August 3, 1898 C.E.), and part of Sam. 53 (17 Muharram 1317 A.H., i.e. May 28, 1899 C.E.). Rothschild lists in his "Index des copistes et des rédacteurs d'actes de vente" on p. 159 also "Sam. 55, f. 52: 1317 H./1899," but this seems to be a misprint.

37. MSS sam 1 and sam 3 in the Oriental Institute of the Academy of Sciences of the USSR in Leningrad/St. Petersburg; for a description see Shunnar, Katalog, 161-162 (sam 1) and p. 160 (sam 3); the dates of completion of both mansucripts is 1896 .

38. BL Or 10723 (see Shunnar, Katalog, 69-70 and Tafel XIII,4) and possibly MS sam N22 in the house of the high priest in Nablus (Shunnar, Katalog, 116; the title AL-K A HIN must be an error). Whereas the former is not dated, the latter is dated 1335 A.H., i.e. 1916/17 C.E.
39. See above n. 38. If this particular manuscript was not copied by him, Ryl Sam 35 has to be used to calculate Aziz b. Jacob's death. The cryptogram of this his 36th Torah is dated 1331 A.H. If he died shortly after finishing Ryl Sam 35, he may even have died in his late thirties. The cryptogram extends from fol. 250r (Deut. 16:18) to fol. 261r (Deut. $27: 8$ ). Aziz b. Jacob's hand ends at the foot of fol. $264 \mathrm{v}$; from $265 \mathrm{r}$ to the end the hand is that of Abisha b. Pinhas. Abisha may not have completed what was left until some time after Aziz b. Jacob's death, i.e. Aziz b. Jacob may have been 41 or 42 years old when he died. In a long poem at the end of the manuscript Abisha notes that the scribe "died in the fullness of time before finishing it" (Robertson, Catalogue II, col. 10), and that he bought it, completed it and bound it in leather; ten years later, i.e. in 1928, he vocalized it at the request of Moses Gaster.

40. His father Jacob died in 1312 A.H., i.e. $1894 / 95$ C.E.; see the genealogical table of the Danfi family in Cowley, Samaritan Liturgy, XLVII.

41. They are Nablus 158, 159, 160, and 167. For a description see Shunnar, Katalog, 145-146, 147.

42. In the Seminar für Semitistik und Arabistik-MS Sam. 26; cf. Shunnar, Katalog, 183 with Tafel XVIII, 1.

43. Cf. Shunnar, Katalog, 201 : addition to LC Sam. MS 9.

44. Shelabi and Halabi are different forms of the same name.

45. Robertson, Catalogue II, col. 165.

46. The text is printed in A. E. Cowley, Samaritan Liturgy (Oxford: Clarendon, 1909), 284-334.

47. See Rothschild, Catalogue, 106.

48. Cf. Crown, "Studies" IV, no. 252.

49. See Robertson, Catalogue II, cols. 275-276. For some of his works see Crown, "Studies" IV, no. 252; the following are to be added to that list: BL Or 10443 (1906 C.E.) (cf. Shunnar, Katalog, 55 and Tafel X, 4), BL Or 10877 (1909 C.E.) (Shunnar, Katalog, 75-76 
and Tafel XIV, 4), BL Or 12293 (1913 C.E.) (Shunnar, Katalog, 9091 and Tafel XV, 9), BL Or 10861 (1911 C.E.) (Shunnar, Katalog, 94-95; the author of the work was his father Pinhas [Khadr] b. Isaac who wrote it in 1292 A.H., i.e. 1875 C.E.), and Sassoon 378 (1905 C.E.) (cf. Sassoon, Obel Dawid, 587) and 396 (1911 C.E.) (cf. Sassoon, Obel Dawid, 588). 